\title{
Formation of Humic Substances in Weathered MSWI Bottom Ash
}

\author{
Haixia Zhang ${ }^{1}$ and Takayuki Shimaoka ${ }^{2}$ \\ ${ }^{1}$ School of Urban Construction, Hebei University of Engineering, Handan 056038, China \\ ${ }^{2}$ Department of Urban and Environmental Engineering, Kyushu University, Fukuoka 819-0395, Japan
}

Correspondence should be addressed to Haixia Zhang; zhanghaixia2002@sina.com

Received 2 April 2013; Accepted 15 May 2013

Academic Editors: S. Niranjan, L. Wang, and Q. Wang

Copyright ( 2013 H. Zhang and T. Shimaoka. This is an open access article distributed under the Creative Commons Attribution License, which permits unrestricted use, distribution, and reproduction in any medium, provided the original work is properly cited.

\begin{abstract}
The study aimed at evaluating the humic substances (HSs) content from municipal solid waste incinerator (MSWI) bottom ash and its variation with time and the effect of temperature on HSs formation. The process suggested by IHSS was applied to extract HSs from two different bottom ash samples, and the extracted efficiency with $\mathrm{NaOH}$ and $\mathrm{Na}_{4} \mathrm{P}_{2} \mathrm{O}_{7}$ was compared. MSWI bottom ash samples were incubated at $37^{\circ} \mathrm{C}$ and $50^{\circ} \mathrm{C}$ for 1 year. HSs and nonhumic substances were extracted from the bottom ash sample with different incubated period by $0.1 \mathrm{M} \mathrm{NaOH} / \mathrm{Na}_{4} \mathrm{P}_{2} \mathrm{O}_{7}$. Results show that the rate of humic acid formation increased originally with incubation time, reached a maximum at 12 th week under $37^{\circ} \mathrm{C}$ and at 18 th week under $50^{\circ} \mathrm{C}$, and then decreased with time. More humic acid in MSWI bottom ash was formed under $50^{\circ} \mathrm{C}$ incubated condition compared with that incubated under $37^{\circ} \mathrm{C}$. Also, the elemental compositions of HSs extracted from bottom ash are reported.
\end{abstract}

\section{Introduction}

Incineration process displays an important role in the municipal solid waste (MSW) management in Japan. In the recent years, approximately $78 \%$ by weight of MSW is incinerated. Incineration is a multipurpose strategy aiming at fighting pollution of environment, energy saving, maximizing benefits of waste, mineralizing and stabilizing waste, and reducing the volume of waste. However, in practice, organic matters in MSW are not completely oxidized by incineration. A few percentage of partially unburned organic waste materials still exist with subsequent formation of new organic compounds being left behind forming the bottom ash [1-5]. European countries restrict the organic matter content in the landfill waste to $5 \%$ in the aim to reduce the pollution from landfill waste [6]. Several researches showed that dissolved organic matter (DOM) in MSWI bottom ash leachate contributes to Cu leaching $[7,8]$. The DOM of MSWI bottom ash also would lead to carbonization and to $\mathrm{pH}$ value decrease in landfill site [2].

Organic matter in MSWI bottom ash is divided into humic substances (HSs, mainly composed of humic acid and fulvic acid) and nonhumic substances (NHS), based on the soil organic matter classification. HSs widely exist in the natural environment and have a high affinity for binding heavy metals and organic pollutants. Humic acid and fulvic acid have been identified as important DOC subfractions contributing to the complexation of contaminants [9]. The study by Zomeren and Comans [8] found that humic acid and fulvic acid contributed to $0.3-0.6 \%$ and $14-26 \%$ DOC, respectively, in the leachate from MSWI bottom ash. Their study further suggests that the fulvic acid-type components exist in MSWI bottom ash leachates are likely responsible for $\mathrm{Cu}$ leaching from bottom ash [10]. The study by Kim revealed that the leaching concentration of dioxins increased with advanced humicification and showed relatively good correlation to DOC [11]. However, there was little information about the formation and decomposition of HSs in MSWI bottom ash.

This work compared the efficiency of $\mathrm{NaOH}$ and $\mathrm{Na}_{4} \mathrm{P}_{2} \mathrm{O}_{7}$ reagents on the extraction HSs from MSWI bottom ash and the effect of temperature on the formation of humic acid from the incineration of the MSW bottom ash. A lab-scale 


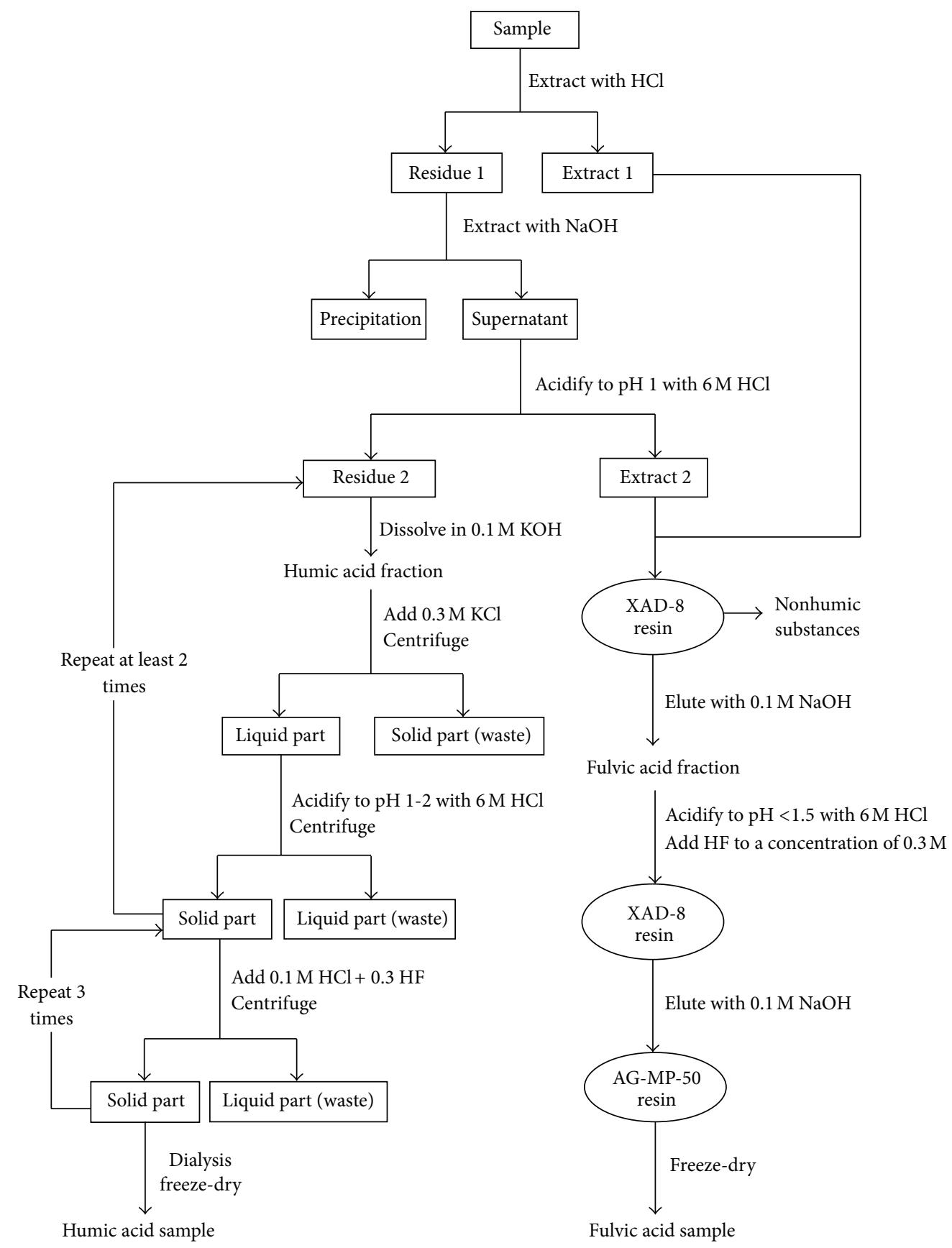

FIGURE 1: Schematic diagram of fractionation of humic substances and nonhumic substances.

incubation facility was used to help exploration of the humic acid formation mechanism.

\section{Materials and Methods}

2.1. Materials and Sampling. The fresh quenched MSWI bottom ashes were taken from $\mathrm{O}$-incineration plant and $\mathrm{R}$ incineration plant, named as O-BA and R-BA. O-incineration plant was operated on a semicontinuous type and incinerated at $850^{\circ} \mathrm{C}$ with a daily treatment capacity of $130 \mathrm{t} / \mathrm{d}(65 \mathrm{t} / 16 \mathrm{~h} \times$ 2). R-incineration plant applied stoker furnace operated on a continuous type, with an incineration capacity of $900 \mathrm{t} / \mathrm{d}$ $(300 t \times 3)$ and the temperature in the combustion chamber was $900^{\circ} \mathrm{C}$. The two bottom ash samples and a crushed incombustibles sample were passed through $4.75 \mathrm{~mm}$ sieve.

2.2. Extraction of Humic Substances. Organic matter in MSWI bottom ash contains humic and fulvic acids together with other nonhumin substances. Humic acid and fulvic acid were separated from solid samples applying the method of international humic substances society (IHSS). Figure 1 shows the conceptual steps of the separation technology. 
Step 1 (extraction with $\mathrm{HCl}$ ). Distilled water was added to the sample in the container to maintain $\mathrm{L} / \mathrm{S}$ ratio $<10$. Aqueous fluid is then acidified using $\mathrm{HCl}$ to a $\mathrm{pH}$ value of 1-2. Adjust the L/S ratio to 10 , and the container was closed for shaking for 1 hour. The container was then centrifuged followed by filtration using filter paper to attain residue 1 and extract 1 . This step is helpful to remove part of carbonate in MSWI bottom ash.

Step 2 (extraction with $\mathrm{NaOH}$ ). Neutralize the residue 1 using $\mathrm{NaOH}$ to $\mathrm{pH} 7$ followed by dilution with $0.1 \mathrm{M} \mathrm{NaOH}$ under an atmosphere of $\mathrm{N}_{2}$ to attain L/S of 10. Shake the solution under atmosphere of $\mathrm{N}_{2}$ for 4 hours. Supernatant was separated from the precipitate by centrifugation and filtration. The supernatant was acidified to $\mathrm{pH} 1$ with $\mathrm{HCl}$ and then centrifuged to obtain extract 2 and residue 2 .

In this step, $\mathrm{Na}_{4} \mathrm{P}_{2} \mathrm{O}_{7}$ or mixture of $\mathrm{NaOH} / \mathrm{Na}_{4} \mathrm{P}_{2} \mathrm{O}_{7}$ was also applied instead of $\mathrm{NaOH}$.

Step 3 (purification of humic acid fraction). Dissolve the residue 2 using $0.1 \mathrm{M} \mathrm{KOH}$ under $\mathrm{N}_{2}$ to obtain humic acid fraction. Add $0.3 \mathrm{M} \mathrm{KCl}$ solution to humic acid fraction to reach L/S 10. Aqueous fluid was separated from the solid resides by centrifugation and filtration to obtain solid part and liquid part. Waste the solid part and liquid part was acidified to $\mathrm{pH} \mathrm{1-2}$ using $\mathrm{HCl}$ and then centrifuged. Solid part was separated by centrifugation. Repeat the process previously mentioned at least 2 times.

Sequentially, dissolve the solid part using $0.1 \mathrm{M}$ $\mathrm{HCl} / 0.3 \mathrm{M}$ hydrofluoric acid (HF) solution in a plastic container. Shake the solution for 24 hours. Solid part was separated from the liquid part by centrifugation and filtration. Repeat the process previously mentioned 3 times. Transfer the solid part to a dialysis tube by slurring with water and dialyze against distilled water until the dialysis water gives a negative $\mathrm{Cl}^{-}$test with the $\mathrm{AgNO}_{3}$. At last, the solid part from dialysis tube was freeze-dried to obtain the solid humic acid sample.

Step 4 (purification of fulvic acid fraction). NHS was recovered from the solutions obtained from Steps 1 and 2 applying resin exchange technique. The resin used was XAD-8, ionexchange resin.

Elute the column with $0.1 \mathrm{M} \mathrm{NaOH}$. Pass eluate through $\mathrm{H}^{+}$-saturated cation exchange resin (AG-MP-50). Freeze-dry the eluate to recover the $\mathrm{H}^{+}$-saturated fulvic acid.

The concentrations of humic acid fraction, fulvic acid fraction, and NHS fraction in carbon were determined with a TOC analyzer (TOC-V, Shimadzu Co.).

2.3. Incubation Experiment. The pretreatment R-BA was prepared for the incubation experiments. About $4 \mathrm{~kg} \mathrm{R}$ BA was filled in each stainless steel container with untight covers. The containers were put in constant temperature ovens setting at $37^{\circ} \mathrm{C}$ and $50^{\circ} \mathrm{C}$, respectively. The incubation experiments were continued for one year under aerobic conditions. During the incubation process, the water contents

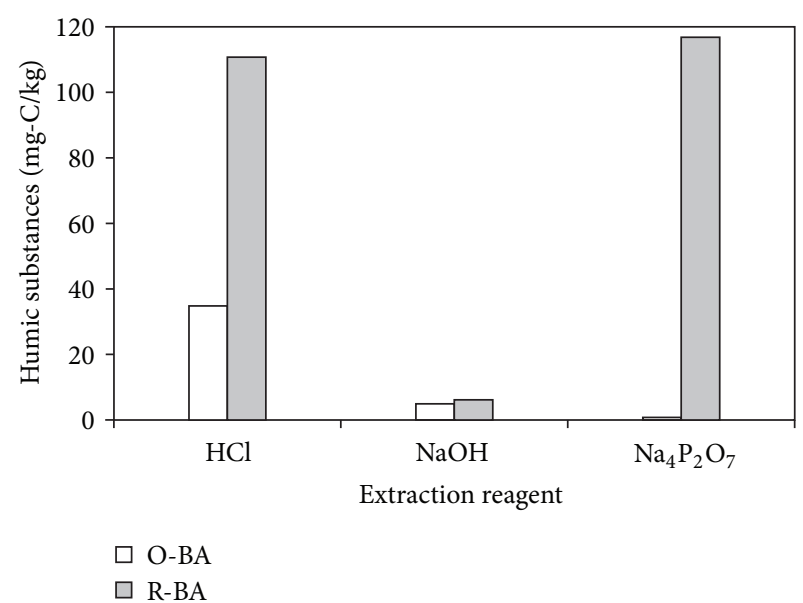

FIGURE 2: Amount of humic substances extracted from R-BA and $\mathrm{O}-\mathrm{BA}$ by $\mathrm{HCl}, \mathrm{NaOH}$, and $\mathrm{Na}_{4} \mathrm{P}_{2} \mathrm{O}_{7}$ in sequence.

of the samples were adjusted to $30 \%$ by adding distilled water every day, simultaneously mixing the samples.

Approximately $200 \mathrm{~g}$ samples were taken out from the containers after $2,4,8,12,18,24,32,36,44$, and 52 weeks of incubation period. These samples were air-dried, grinded, and sieved through a $2 \mathrm{~mm}$ mesh. The pretreated samples were kept in closed plastic bags and saved under $4^{\circ} \mathrm{C}$ till analysis.

2.4. Elementary Analysis of Humic Substances. Carbon, hydrogen, and nitrogen contents in eluted humic, fulvic acid were determined with the help an elemental analyzer (YANAKO CHN coder MT-50, Yanagimoto Co.).

\section{Results and Discussion}

3.1. Effect of Extraction Reagent on Humic Substances Extraction. The amounts of HSs extracted from O-BA and R$\mathrm{BA}$ by three extraction reagents are shown in Figure 2. HSs extracted by $\mathrm{HCl}, \mathrm{NaOH}$, and $\mathrm{Na}_{4} \mathrm{P}_{2} \mathrm{O}_{7}$ from O-BA accounted for $86 \%, 12 \%$, and $2 \%$ of total HSs amount, while these values were $47 \%, 3 \%$, and $50 \%$ for R-BA. The data indicated that $\mathrm{HCl}$ was effective to extract $\mathrm{HSs}$ from both MSWI bottom ash samples and $\mathrm{NaOH}$ had minor effect on extraction of $\mathrm{HSs}$ from the two samples. $\mathrm{Na}_{4} \mathrm{P}_{2} \mathrm{O}_{7}$ almost could not extract HSs from O-BA, but it was an effective reagent to extract HSs from R-BA.

IHSS has been suggested that the material should be dissolved in dilute $\mathrm{HCl}$ before the alkaline extractant is applied, which is helpful to remove $\mathrm{Ca}$ and other polyvalent cations and increases the efficiency of extraction of organic matter with alkaline reagents. The previous study has indicated that the main minerals in MSWI bottom ash contain $\mathrm{Ca}$ and other polyvalent cations (such as $\mathrm{Fe}$ and $\mathrm{Al}$ ) [12]. So $\mathrm{HCl}$ is a necessary reagent to extract HSs from MSWI bottom ash. $\mathrm{NaOH}$ has been expected to extract mainly free complexed organic components and $\mathrm{Na}_{4} \mathrm{P}_{2} \mathrm{O}_{7}$ to extract intimately complexed organic part, which can form complexes 
with exchangeable polyvalent cations, thereby breaking down the cation bridges between the exchangeable cations and organic matter $[13,14]$. According to the following reactions postulated by Alexsandrova [15], $\mathrm{Na}_{4} \mathrm{P}_{2} \mathrm{O}_{7}$ are thought to extract $\mathrm{OM}$ by breaking down the cation bridges between $\mathrm{Ca}$ and other polyvalent cations and organic matter and forming insoluble precipitates:

$$
\begin{aligned}
& \mathrm{R}(\mathrm{COO})_{4} \mathrm{Ca}_{2}+\mathrm{Na}_{4} \mathrm{P}_{2} \mathrm{O}_{7} \longrightarrow \mathrm{R}(\mathrm{COONa})_{4}+\mathrm{Ca}_{2} \mathrm{P}_{2} \mathrm{O}_{7} \downarrow \\
& 2\left[\mathrm{RCOOX}(\mathrm{OH})_{2}\right](\mathrm{COO})_{2} \mathrm{Ca}+\mathrm{Na}_{4} \mathrm{P}_{2} \mathrm{O}_{7} \\
& \longrightarrow 2\left[\mathrm{RCOOX}(\mathrm{OH})_{2}\right](\mathrm{COONa})_{2}+\mathrm{Ca}_{2} \mathrm{P}_{2} \mathrm{O}_{7} \downarrow
\end{aligned}
$$

According to the experiment results, it could be expected that R-BA contain less free complexed organic matter and considerable amount of complexed organic matter. For the purpose of investigating the HSs content in MSWI bottom ash, here it is suggested to combine $\mathrm{NaOH}$ and $\mathrm{Na}_{4} \mathrm{P}_{2} \mathrm{O}_{7}$ to extract HSs from MSWI bottom ash, following $\mathrm{HCl}$ extraction.

The total HSs amounts extracted from the two bottom ash samples differed to a large extent. O-BA only contained $40.5 \mathrm{mg}-\mathrm{C} / \mathrm{kg}$ HSs, but R-BA contained $234 \mathrm{mg}-\mathrm{C} / \mathrm{kg}$ HSs which was almost 6 times higher than that of O-BA. This may be caused by the fact of the different composition of MSW treated in the two incineration plants. In addition, the different incinerator type and incineration temperature can also have an effect on the organic components in the MSWI bottom ash.

\subsection{Effect of Temperature on the Humic Substances Formation.}

Figure 3 shows the content of humic acid, fulvic acid content as well as HSs in the R-BA incubated under $37^{\circ} \mathrm{C}$. Fresh R-BA contained $279 \mathrm{mg}-\mathrm{C} / \mathrm{kg}$ HSs $(23 \mathrm{mg}-\mathrm{C} / \mathrm{kg}$ humic acid and $256 \mathrm{mg}-\mathrm{C} / \mathrm{kg}$ fulvic acid) and $361 \mathrm{mg}-\mathrm{C} / \mathrm{kg}$ NHS. Thus it can be seen that fresh MSWI bottom ash contained HSs after experiencing an incineration process. In the case of the bottom ash samples incubated under $37^{\circ} \mathrm{C}$, humic acid concentration was in the range of $6-74 \mathrm{mg}-\mathrm{C} / \mathrm{kg}$ and fulvic acid in the range of $103-286 \mathrm{mg}-\mathrm{C} / \mathrm{kg}$ through the incubation period. The NHS content in R-BA increased at the initial incubation stage, and it reached $496 \mathrm{mg}-\mathrm{C} / \mathrm{kg}$ at 12 th weeks then it began to decrease.

For the R-BA samples incubated under $50^{\circ} \mathrm{C}$ shown in Figure 4, humic acid was in the range of $16-358 \mathrm{mg}-\mathrm{C} / \mathrm{kg}$, and fulvic acid in the range of $158-256 \mathrm{mg}-\mathrm{C} / \mathrm{kg}$. Humic acid was produced rapidly under $50^{\circ} \mathrm{C}$ until 18th week and the amount of humic acid once exceeded that of fulvic acid at 18th week, and then humic acid content dropped distinctly. Fulvic acid content was relatively stable through the incubation period. Humic acid mainly comes from the degradation of lignin, and higher temperature was good for lignin degradation [16]. Compared with R-BA incubated under $37^{\circ} \mathrm{C}$, there is more humic acid contained in R-BA incubated under $50^{\circ} \mathrm{C}$.

For MSWI bottom ash incubated under $50^{\circ} \mathrm{C}$, the humic acid content was significantly higher than that of the MSWI bottom ash incubated under $37^{\circ} \mathrm{C}$. Reversely, the highest content value of fulvic acid appeared in the sample incubated

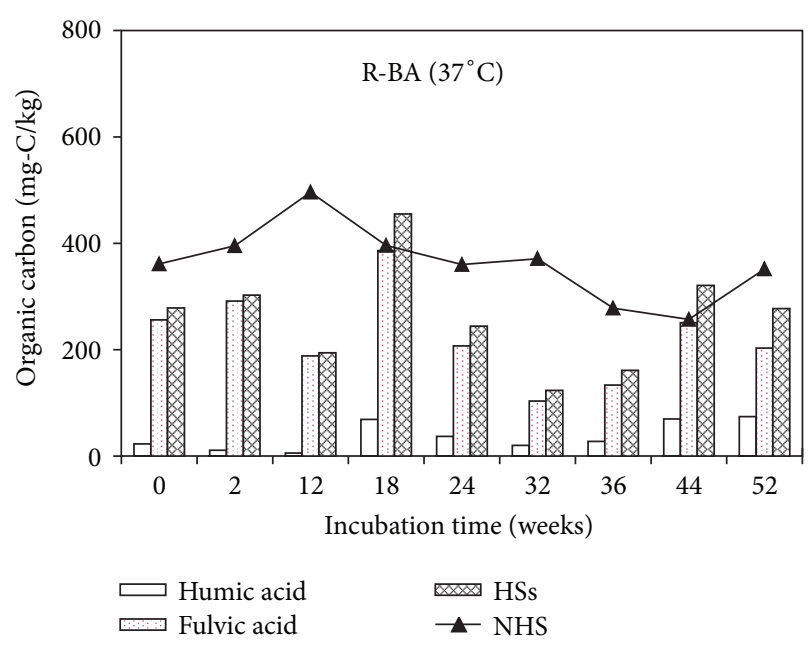

Figure 3: Humic substances and nonhumic substances contents as a function of incubation time in R-BA incubated under $37^{\circ} \mathrm{C}$.

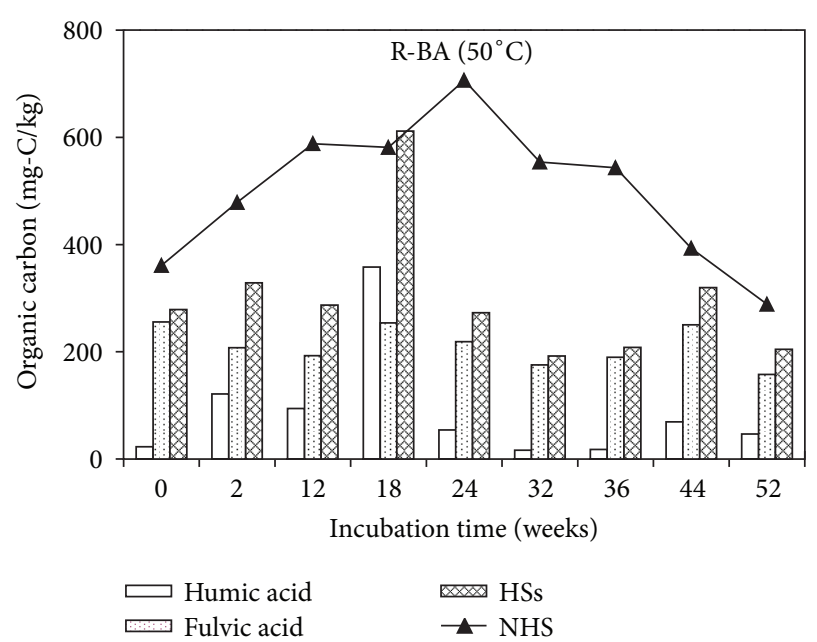

FIGURE 4: Humic substances and nonhumic substances contents as a function of incubation time in R-BA incubated under $50^{\circ} \mathrm{C}$.

under $37^{\circ} \mathrm{C}$, showing that high temperature may be beneficial to the formation of humic acid, while low temperatures are conducive to the accumulation of fulvic acid. The total content of humic acid and fulvic acid amount was higher in the sample incubated under $50^{\circ} \mathrm{C}$ compared with that under $37^{\circ} \mathrm{C}$ and so as NHS.

This shows that temperature is an important environmental factor of HSs formation and transformation. The storage temperature of MSWI bottom ash will affect the HSs content, thereby affecting the migration of heavy metals.

\subsection{Elementary Composition of Humic Substances from MSWI} Bottom Ash. The elementary compositions of humic acid and fulvic acid extracted from R-BA are shown in Table 1 together with the average values of soil HSs in [17]. Compared with the literature data, the content of carbon and hydrogen in HSs extracted from R-BA accorded with those of soil HSs. The extracted HSs from R-BA had a higher content 
TABLE 1: Elementary analysis of humic substance extracted from R-BA.

\begin{tabular}{lcccccc}
\hline & Sample & $\mathrm{C}(\%)$ & $\mathrm{H}(\%)$ & $\mathrm{N}(\%)$ & $\mathrm{O}(\%)$ & $\mathrm{C} / \mathrm{N}$ \\
\hline \multirow{3}{*}{ Humic acid } & Fresh R-BA & 53.68 & 5.63 & 6.52 & 34.17 & 8.23 \\
& 24th weeks incubated R-BA & 54.81 & 5.00 & 5.55 & 34.64 & 9.88 \\
& Tan, 2003 [17] & $53.8-58.7$ & $3.2-6.2$ & $2.6-5.05$ & $39.7-48.8$ & $12.3-17.3$ \\
\hline \multirow{2}{*}{ Fulvic acid } & Fresh R-BA & 46.5 & 4.34 & 1.78 & 47.38 & 26.12 \\
& Tan, 2003 [17] & $40.7-50.6$ & $3.8-7.0$ & $0.8-4.3$ & $32.9-51.9$ & $18.4-37.8$ \\
\hline
\end{tabular}

of nitrogen and lower content of oxygen compared with the soil HSs. HSs decompose slowly and supply nitrogen nutrient to microbial utilization and release carbon dioxide. Simultaneously, the dead microorganism supplies carbon source for HSs synthesis. The loss of nitrogen is substantial compared to carbon. Nitrogen loss caused C/N ratio of MSWI bottom ash to gradually increase with incubation time.

\section{Conclusions}

The study determines the HSs extraction reagent from MSWI bottom ash by comparison of $\mathrm{NaOH}$ and $\mathrm{Na}_{4} \mathrm{P}_{2} \mathrm{O}_{7} . \mathrm{NaOH}$ and $\mathrm{Na}_{4} \mathrm{P}_{2} \mathrm{O}_{7}$ have different extraction efficiency for the studied two MSWI bottom ashes. So $0.1 \mathrm{M} \mathrm{NaOH} / 0.1 \mathrm{M}$ $\mathrm{Na}_{4} \mathrm{P}_{2} \mathrm{O}_{7}$ was recommend to extract $\mathrm{HSs}$ from MSWI bottom ash.

Fresh MSWI bottom ash contains humic acid and fulvic acid. More humic acid was formed during the incubation period and accounted for $8-27 \%$ of the organic fractions in the landfilled MSWI bottom ash. Fulvic acid was contained in the fresh MSWI bottom ash, and its amount was relatively stable. The variation of HSs content in the incubated samples showed a change with incubation time. The results showed that high temperature may be beneficial to the formation of humic acid, while low temperatures are conducive to the accumulation of fulvic acid.

\section{Acknowledgment}

This work was supported by the National Natural Science Foundation of China (Grant no. 51208167).

\section{References}

[1] H. Belevi, D. M. Stampfli, and P. Baccini, "Chemical behaviour of municipal solid waste incinerator bottom ash in monofills," Waste Management and Research, vol. 10, no. 2, pp. 153-167, 1992.

[2] S. Ferrari, H. Belevi, and P. Baccini, "Chemical speciation of carbon in municipal solid waste incinerator residues," Waste Management, vol. 22, no. 3, pp. 303-314, 2002.

[3] E. Rendek, G. Ducom, and P. Germain, "Assessment of MSWI bottom ash organic carbon behavior: a biophysicochemical approach," Chemosphere, vol. 67, no. 8, pp. 1582-1587, 2007.

[4] A. van Zomeren and R. N. J. Comans, "Speciation and characterization of organic carbon in municipal solid waste incinerator (MSWI) bottom ash," in Proceeding of the 5th International Conference on the Environmental and Technical Implication of Construction with Alternative Materials, pp. 657-666, 2003.
[5] S. Zhang, J. Herbell, and B. Gaye-Haake, "Biodegradable organic matter in municipal solid waste incineration bottom ash," Waste Management, vol. 24, no. 7, pp. 673-679, 2004.

[6] S. Rubli, E. Medilanski, and H. Belevi, "Characterization of total organic carbon in solid residues provides insight into sludge incineration processes," Environmental Science and Technology, vol. 34, no. 9, pp. 1772-1777, 2000.

[7] J. A. Meima, A. van Zomeren, and R. N. J. Comans, "Complexation of $\mathrm{Cu}$ with dissolved organic carbon in municipal solid waste incinerator bottom ash leachates," Environmental Science and Technology, vol. 33, no. 9, pp. 1424-1429, 1999.

[8] A. van Zomeren and R. N. J. Comans, "Contribution of natural organic matter to copper leaching from municipal solid waste incinerator bottom ash," Environmental Science and Technology, vol. 38, no. 14, pp. 3927-3932, 2004.

[9] F. J. Stevenson, Humus Chemistry: Genesis, Composition, Reactions, John Wiley \& Sons, New York, NY, USA, 1982.

[10] A. van Zomeren and R. N. J. Comans, "Carbon speciation in municipal solid waste incinerator (MSWI) bottom ash in relation to facilitated metal leaching," Waste Management, vol. 29, no. 7, pp. 2059-2064, 2009.

[11] Y. Kim and M. Osako, "Investigation on the humification of municipal solid waste incineration residue and its effect on the leaching behavior of dioxins," Waste Management, vol. 24, no. 8, pp. 815-823, 2004.

[12] H. Zhang and T. Shimaoka, "Effect of organic matter on leaching behavior of heavy metals from municipal solid waste incineration bottom ash," Memoirs of the Faculty of Engineering, Kyushu University, vol. 67, no. 4, pp. 165-180, 2007.

[13] R. G. Garrett, A. I. MacLaurin, E. J. Gawalko, R. Tkachuk, and G. E. M. Hall, "A prediction model for estimating the cadmium content of durum wheat from soil chemistry," Journal of Geochemical Exploration, vol. 64, no. 1-3, pp. 101-110, 1998.

[14] M. Schnitzer and P. Schuppli, "The extraction of organic matter from selected soils and particle size fractions with $0.5 \mathrm{M} \mathrm{NaOH}$ and $0.1 \mathrm{M} \mathrm{Na}_{4} \mathrm{P}_{2} \mathrm{O}$ solutions," Canadian Journal of Soil Science, vol. 69, no. 2, pp. 253-262, 1989.

[15] L. N. Alexsandrova, "The use of sodium pyrophosphate for isolating free humic substances and their organic-mineral compounds from the soil," Soviet Soil Science, vol. 2, pp. 190197, 1960.

[16] M. Tuomela, M. Vikman, A. Hatakka, and M. Itävaara, "Biodegradation of lignin in a compost environment: a review," Bioresource Technology, vol. 72, no. 2, pp. 169-183, 2000.

[17] K. H. Tan, Humic Matter in Soil and the Environment: Principles and Controversies, Marcel Dekker, New York, NY, USA, 2003. 

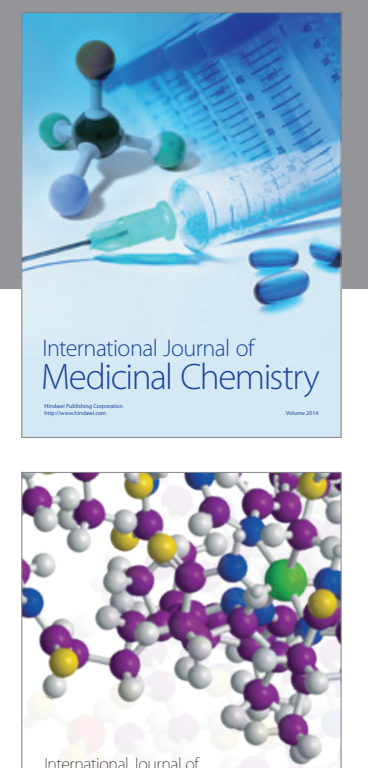

\section{Carbohydrate} Chemistry

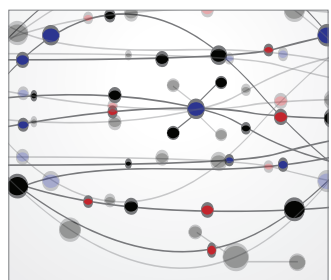

The Scientific World Journal
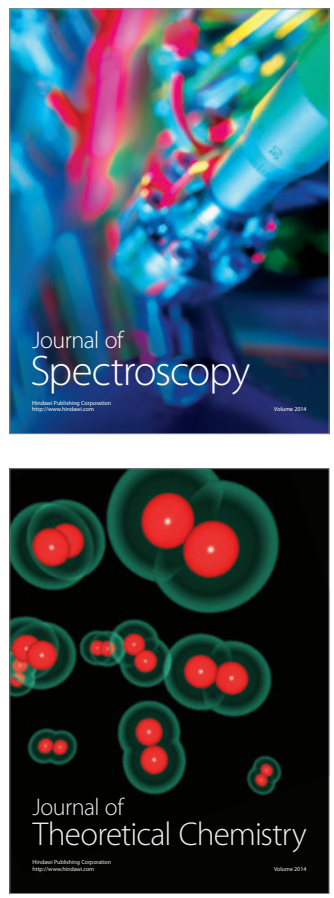
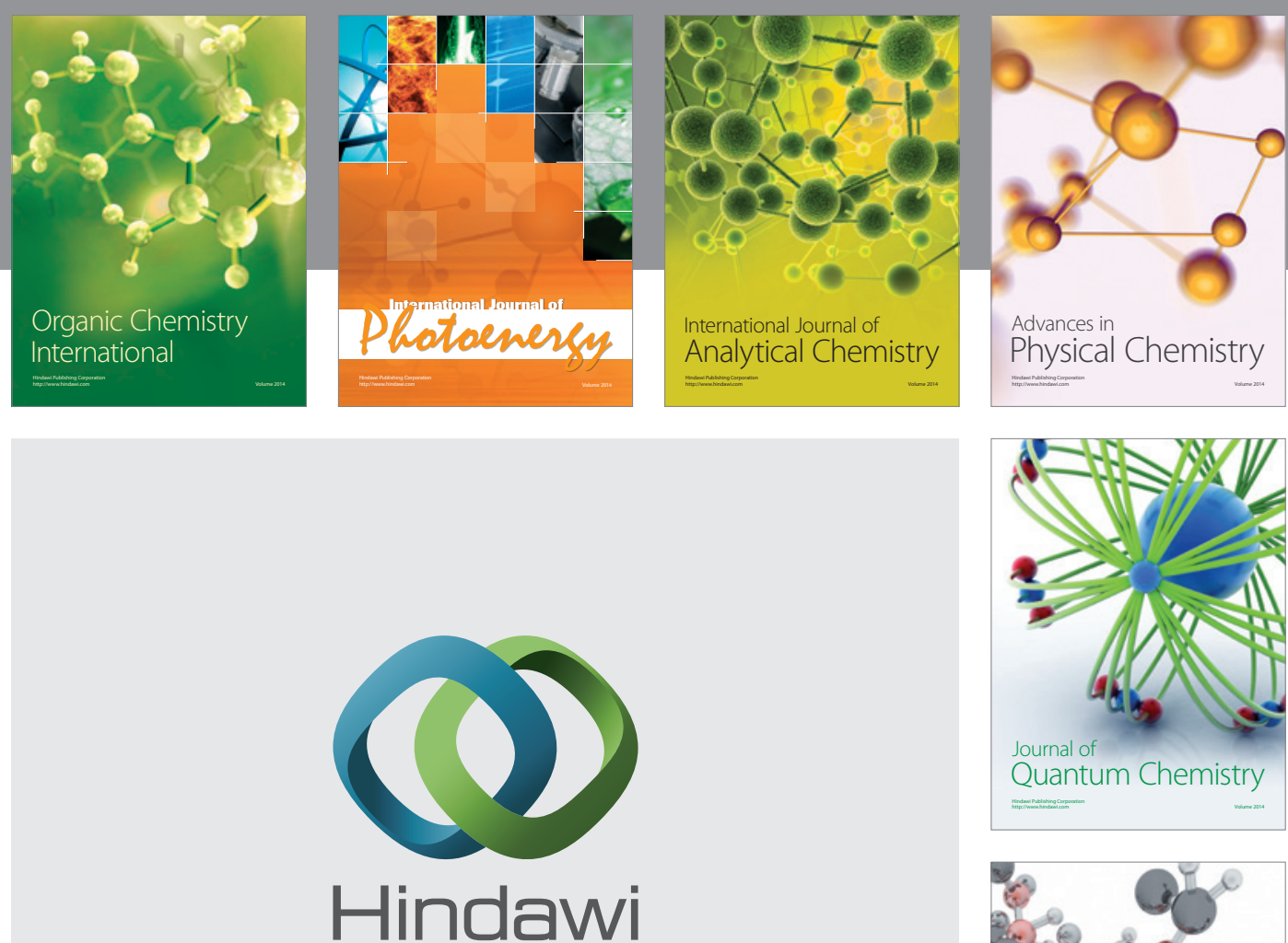

Submit your manuscripts at

http://www.hindawi.com

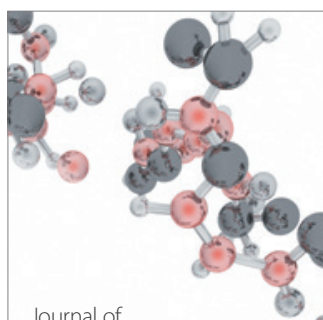

Analytical Methods

in Chemistry

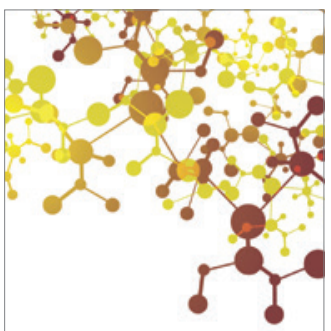

Journal of

Applied Chemistry

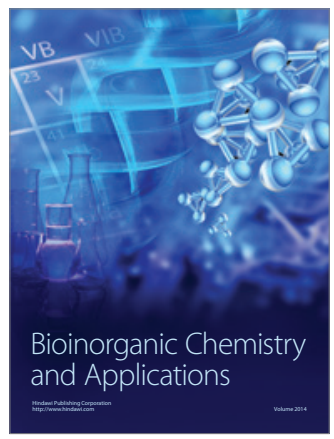

Inorganic Chemistry
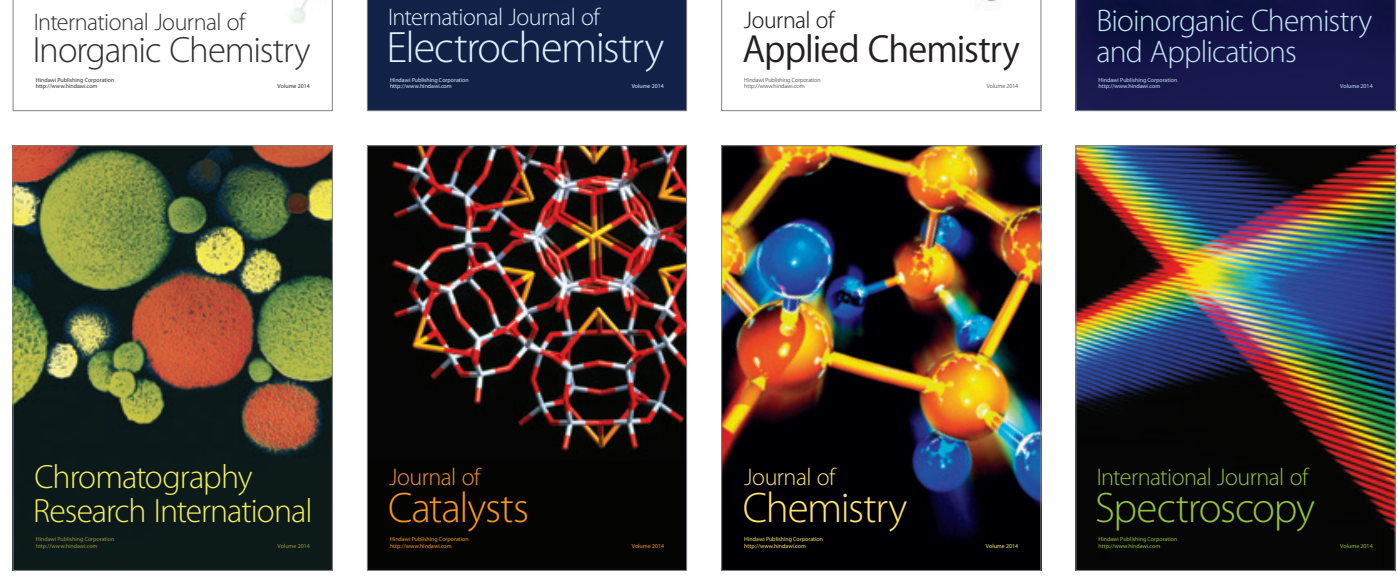